\title{
The Prevalence of Psychiatric Symptoms in The Patients with Behcet's Disease in Shiraz, Southwest of Iran
}

\author{
Fereshteh Bagheri, Arash Mani², Ashkan Tadayyoni, Farnosh Firozi, Mohammad Ali Nazarinia
}

\section{ÖZET:}

İran'ın güneybatısı, Shiraz'daki Behçet hastalarında psikiyatrik belirti sıklıg̃ı

Giriș: Behçet hastalı̃̃ı (BH), ilk olarak 1937 yllında bir Türk Dermatolog̃u olan Hulusi Behçet tarafından oral, genital ve oküler ülser üçüsü ile tanımlanan karmașık bir çoklu sistem sendromudur. Bu çalıșmada BH'den muzdarip hastalarda bazı psikolojik belirtilerin varlıg̃ını araștırmayı amaçladık.

Yöntem: Bu araștırma Haziran 2011-Ag̃ustos 2011 tarihleri arasında İran'ın güneybatısında yer alan Shiraz Shahid Motahari Kliniḡi'nde takip edilen hastalararın arasından rastgele seçilmiş 101 BH hastasından olușan bir örneklem üzerinde yapılan kesitsel bir çalıșma idi. Tüm hastalar Belirti Tarama Listesi-90-Gözden Geçirilmiș (Symptom Checklist, SCL-90-R) ve yaș ve cinsiyet gibi bazı demografik bilgilerin yer aldıg̃ı formları tamamladı. Tüm istatistiksel analizler SPSS istatistik programı (v 17.0) kullanılarak yapıldı.

Bulgular: Sonuçlara göre hastaların \%30.7'si (GSI<0.7) sag̃lıklı iken dig̃erlerinin (\%69.3) çeșitli seviyede belirtileri $(\mathrm{GSI}<0.7)$ mevcuttu. Psikiyatrik belirti alt ölçeklerinden somatizasyon (91.7\%), anksiyete (78\%) ve depresyon $(77.78 \%)$ en sik belirtilerdi. Dig̃er yandan en nadir olan belirti ise korku (34.1\%) idi. Çalışmamızın bulgularına göre kadın hastaların ortalama anksiyete sonuçları erkeklere göre anlamlı derecede yüksekti $(p=0.013)$.

Sonuç: Psikolojik belirtilerinin sıklıg̃ı BH hastalarında dikkat çekiciydi. Bu nedenle hekimler, hastalarının hastalıkları sırasında gelișebilecek olası psikiyatrik bozuklukları saptayabilmek için onları takip etmelidirler.

Anahtar sözcükler: Behçet, psikiyatrik belirti, sıklık, SCL-90-R

Journal of Mood Disorders 2013;3(1):28-32

\section{ABSTRACT:}

The prevalence of psychiatric symptoms in the patients with Behcet's disease in Shiraz, Southwest of Iran

Introduction: Behçet's disease (BD), first explained in 1937 by the Turkish dermatologist Hulusi Behçet, is a complicated multisystem syndrome described by a triad of oral, genital, and ocular ulcers. The present study aimed to investigate existence of some psychological symptoms in the patients suffering from $\mathrm{BD}$.

Method: The present research was a cross-sectional one, which was conducted on a sample of 101 randomly selected patients with BD who had been followed up at Shahid Motahari Clinic, Shiraz, Southwest of Iran, from June 2011 to August 2011. All of the patients completed the Symptom Checklist-90-Revised (SCL-90-R) and some demographic information, such as age and gender. All statistical analyses were performed using the SPSS statistical software (v. 17.0).

Results: According to the results, $30.7 \%$ of the patients were healthy (GSI<0.7), while others (69.3\%) had different levels of symptoms (GSI>0.7). In psychiatric symptoms' subscales, somatization (91.7\%), anxiety (78\%), and depression $(77.78 \%)$ were the most prevalent symptoms. On the other hand, phobia had the lowest prevalence (34.1\%). Based on our findings, the females' average anxiety score was significantly higher than that of the male subjects $(p=0.013)$.

Conclusion: The prevalence of psychological symptoms was remarkable in the patients with BD. Therefore, physicians should monitor their patients in order to detect the possible psychiatric disorders they might develop during their disease.

Key words: Behcet, psychiatric symptom, prevalence, SCL90-R

Journal of Mood Disorders 2013;3(1):28-32
'Student Research Committee, Shiraz University of Medical Sciences, Shiraz, Iran 2Department of Psychiatry and Psychology, Shiraz University of Medical Sciences, Shiraz, Iran

${ }^{3}$ Department of Rheumatology, Shiraz University of Medical Sciences, Shiraz, Iran

Yazıșma Adresi / Address reprint requests to: Fereshteh Bagheri, Student Research Committee, Shiraz Medical School, Shiraz University of Medical Sciences, Shiraz, Iran

Telefon / Phone: 0098-9176046722

Elektronik posta adresi / E-mail address: bagheri.fereshte@yahoo.com

Kabul tarihi / Date of acceptance: 19 Şubat 2013 / February 19, 2013

\section{Bag̃ıntı beyanı:}

F.B., A.M., A.T., F.F., M.A.N.: Yazarlar bu makale ile ilgili olarak herhangi bir çıkar catısması bildirmemiștir.

\section{Declaration of interest:}

F.B., A.M., A.T., F.F., M.A.N.: The authors reported no conflict of interest related to this article.

\section{INTRODUCTION}

Behçet disease (BD), first explained in 1937 by the Turkish dermatologist Hulusi Behçet (1), is a complicated multisystem syndrome described by a triad of oral, genital, and ocular ulcers (2). Besides its characteristic triad, BD frequently involves cardiovascular, pulmonary, neurological, articular, and gastrointestinal systems causing a mixture of clinical problems and leads to temporary or permanent functional disability (3). The cause of BD is unknown and investigations of probable virological, hormonal, and immunological processes are in progress (4).

The complicated pattern of signs and symptoms in BD can cause different levels of activity restriction and limitations in the individuals' lifestyle, leading to troubles 
Table 1: Cut off points of the Iranian version of SCL-90-R (Noorbala et al., 2010)

\begin{tabular}{lllll} 
Cut-off points & Healthy & Borderline & Sick & Extremely sick \\
\hline Somatization & $0-3.5$ & $3.6-11.5$ & $11.6-20.5$ & $20.6-48$ \\
Depression & $0-6.5$ & $6.6-15.5$ & $15.6-34.5$ & $34.6-52$ \\
Anxiety & $0-4.5$ & $4.6-10.5$ & $10.6-25.5$ & $25.6-40$ \\
Interpersonal sensitivity & $0-6.5$ & $6.6-15.5$ & $15.6-26.5$ & $26.6-36$ \\
Hostility & $0-2.5$ & $2.6-7.5$ & $7.6-16.5$ & $16.6-24$ \\
OCD & $7-0$ & $8-11$ & $12-26$ & $27-40$ \\
Phobia & $0-4$ & $5-12$ & $13-20$ & $21-28$ \\
Paranoid thoughts & $0-7$ & $8-13$ & $14-19$ & $20-24$ \\
Psychosis & $0-3$ & $4-6$ & $7-23$ & $24-40$ \\
Others & $0-2$ & $3-6$ & $7-17$ & $18-28$
\end{tabular}

in their psychological health $(5,6)$.

Although it hasn't been proved yet, in some studies, the progression of the disorder, functional weakening, central nervous system involvement, and steroid use have been suggested as the related causes of the psychological symptoms in BD patients $(7,8)$.

The psychological sides of Behcet's syndrome have been peripherally discussed in many reviews and case reports; however, a limited number of articles has exclusively dealed with this aspect (9). Borson described a man, in whom a progressive psychological syndrome was the main manifestation of his disorder (6). Moreover, some studies have found considerable primary and secondary associations between emotional disorders and Behcet's syndrome. Nevertheless, the vague pathogenesis of the somatic condition needs further investigation to clarify this relationship (4). Furthermore, clarification of this relationship may help the physicians to improve the quality of their patients' lives.

The present study aimed to investigate the existence and prevalence of psychological symptoms in the patients with $\mathrm{BD}$ in order to contribute to the field in reaching above-mentioned goals.

\section{MATERIALS AND METHODS}

The present cross-sectional study was conducted on a sample of 101 randomly selected patients with BD who had been followed up at Shahid Motahari Clinic, Shiraz, southern Iran, from June 2011 to August 2011. The patients, who had a positive history of brain-damage, mental retardation, and/or psychosis before onset of their disease, were excluded from the study. All the study subjects completed the Symptom Checklist -90-Revised
(SCL-90-R) and some demographic information, such as age and gender.

The SCL-R-90 is an extensively used and validated self-reported symptom inventory designed to reflect the psychological symptoms detected in psychiatric and medical patients (10). Each item of the questionnaire was rated by the patients on a five-point scale of distress from 0 (none) to 4 (extreme) which they have experienced during the last 7 days. The questionnaire consists of nine psychological dimensions; i.e., Somatization, Obsessive Compulsive, Interpersonal Sensitivity, Depression, Anxiety, Hostility, Phobic Anxiety, Paranoid, and Psychoticism, and the higher the score, the greater the distress in the psychological aspects.

The Iranian version of SCL-90-R has been validated in many studies in various community samples in Iran. In 1995, Bagheri and his colleagues estimated the validity of the questionnaire as about $97 \%$ and its sensitivity, specificity, and reliability as $94 \%, 98 \%$, and $96 \%$, respectively (11). Table 1 shows the cut off points of the Iranian version of SCL-90-R according to the study conducted by Noorbala et al. (12).

\section{Statistical Analysis}

The psychological dimensions of the patients were summarized by descriptive statistics (frequency and percentage). In addition, independent sample T-test was used in order to compare the mean differences of male and female subjects regarding the psychological syndrome. All the statistical analyses were performed through the SPSS statistical software (v. 17.0) and $\mathrm{p}<0.05$ was considered as statistically significant. 


\section{RESULTS}

The present study was conducted on $101 \mathrm{BD}$ patients (4 with missing data) with the mean age of $38.66 \pm 11.75$ and the age range of 15 to 65 years old. In addition, 31 patients were male $(30.69 \%)$ and 70 were female $(69.30 \%)$. None of the patients had any history of brain-damage, mental retardation, and psychosis.
Based on the cut-off point of GSI which was reported in a study (0.7)(13), 30.7\% of the patients were healthy $(\mathrm{GSI}<0.7)$ and others $(69.3 \%)$ had different levels of disorders (GSI>0.7). In the psychiatric symptoms' subscales, somatization (91.7\%), anxiety $(78 \%)$, and depression $(77.78 \%)$ were the most prevalent symptoms. On the other hand, phobia had the lowest prevalence $(34.1 \%)$. The prevalence of other symptoms is shown in

Table 2: The prevalence of psychological symptom levels according to SCL-90-R

\begin{tabular}{llllll} 
& Healthy & Borderline & Sick & Extremely sick & Total \\
\hline Somatization & $7(8.3 \%)$ & $24(28.6 \%)$ & $20(23.8 \%)$ & $33(39.3 \%)$ & 84 \\
Depression & $17(22.4 \%)$ & $23(30.3 \%)$ & $33(43.4 \%)$ & $3(3.9 \%)$ & 76 \\
Anxiety & $18(22 \%)$ & $25(30.5 \%)$ & $35(42.7 \%)$ & $4(4.9 \%)$ & 82 \\
Interpersonal sensitivity & $21(25.9 \%)$ & $45(55.6 \%)$ & $15(18.5 \%)$ & 0 & 81 \\
Hostility & $22(25.9 \%)$ & $39(45.9 \%)$ & $24(28.2 \%)$ & 0 & 85 \\
OCD & $26(31 \%)$ & $24(28.6 \%)$ & $32(38.1 \%)$ & $2(2.4 \%)$ & 84 \\
Phobia & $54(65.9 \%)$ & $21(25.6 \%)$ & $7(8.5 \%)$ & 0 & 82 \\
Paranoid thoughts & $51(65.4 \%)$ & $19(24.4 \%)$ & $6(7.7 \%)$ & $2(2.6 \%)$ & 78 \\
Psychosis & $25(30.9 \%)$ & $14(17.3 \%)$ & $38(46.9 \%)$ & $4(4.9 \%)$ & 81
\end{tabular}

Table 3: Comparison of SCL-90-R scores in the patients with BD by gender

\begin{tabular}{|c|c|c|c|}
\hline Gender & $\mathbf{t}$ & Mean \pm Std Deviation & p value* \\
\hline $\begin{array}{c}\text { Somatizatio } \\
\text { male } \\
\text { female }\end{array}$ & -1.514 & $\begin{array}{l}14.5769 \pm 9.3002 \\
18.3793 \pm 11.1824\end{array}$ & 0.134 \\
\hline $\begin{array}{l}\text { OCD } \\
\text { male } \\
\text { female }\end{array}$ & -0.488 & $\begin{array}{l}10.7500 \pm 6.3674 \\
11.6333 \pm 7.8890\end{array}$ & 0.627 \\
\hline $\begin{array}{l}\text { Interperson } \\
\text { male } \\
\text { female }\end{array}$ & -0.169 & $\begin{array}{l}10.0435 \pm 6.2193 \\
10.291 \pm 5.9176\end{array}$ & 0.866 \\
\hline $\begin{array}{c}\text { Depression } \\
\text { male } \\
\text { female }\end{array}$ & -1.568 & $\begin{array}{l}12.8696 \pm 9.3142 \\
16.6981 \pm 9.9665\end{array}$ & 0.121 \\
\hline $\begin{array}{l}\text { Anxiety } \\
\text { male } \\
\text { female }\end{array}$ & -2.077 & $\begin{array}{l}8.6250 \pm 5.1059 \\
12.5517 \pm 8.6393\end{array}$ & 0.013 \\
\hline $\begin{array}{l}\text { Hostility } \\
\text { male } \\
\text { female }\end{array}$ & 1.302 & $\begin{array}{l}6.0417 \pm 4.2373 \\
4.9672 \pm 3.0549\end{array}$ & 0.266 \\
\hline $\begin{array}{l}\text { Phobia } \\
\text { male } \\
\text { female }\end{array}$ & -0.921 & $\begin{array}{l}3.3913 \pm 3.0412 \\
4.4237 \pm 5.0145\end{array}$ & 0.261 \\
\hline $\begin{array}{c}\text { Paranoid th } \\
\text { male } \\
\text { female }\end{array}$ & 0.905 & $\begin{array}{l}7.2917 \pm 5.3118 \\
6.2222 \pm 4.5833\end{array}$ & 0.368 \\
\hline $\begin{array}{c}\text { Psychosis } \\
\text { male } \\
\text { female }\end{array}$ & -0.926 & $\begin{array}{l}7.2083 \pm 6.0288 \\
8.8421 \pm 7.6969\end{array}$ & 0.311 \\
\hline
\end{tabular}


Table 2. Based on our findings, the anxiety score was significantly higher in females in comparison to males $(\mathrm{p}=$ 0.013). Other p-values are reported in Table 3.

\section{DISCUSSION}

The patients who experience chronic diseases, such as $\mathrm{BD}$, sometimes suffer from psychological disorders in addition to the physical symptoms of the disease, which subsequently could have deeply negative effects on the patients' daily lives (6). Our study results showed that some of these psychological manifestations were present in $\mathrm{BD}$ patients among which, somatization was the most prevalent symptom $(91.7 \%)$ followed by anxiety $(78 \%)$ and depression (77.78\%), respectively. In addition, no statistically significant difference was found between the female and male patients, except for anxiety $(\mathrm{p}=0.013)$.

In general, corticosteroid administration is considered as the main treatment for all the manifestations of the disorder, but the efficient dosage is variable. The primary response to this drug is desirable; however, relapse and remission is quite common in this disease (9).

Up to now, a limited number of studies have been conducted on the psychological aspects of $\mathrm{BD}$ and anxiety and depression were frequently detected in this disease $(14,15)$. Similarly, the results of the current study showed that anxiety and depression were quite prevalent; however, somatization revealed the highest prevalence, which is consistent with the findings of some other studies (5). The patients with somatization have a tendency to experience somatic distress as a result of psychosocial stress and seek medical help and may perceive to have a major medical, social, or economic problems. Therefore, if this problem becomes a persistent and chronic condition, it could be very costly and difficult to prevent and control (16). Hence, the prevention and early diagnosis of somatization could play an important role in treating BD.

Blackford et al. investigated the effect of the cutaneous manifestations of $\mathrm{BD}$ on the quality of life and demonstrated that skin signs of BD, as well as mouth and genital ulcers caused the corruption of personal relationships (17). In the same line, the findings of the present study indicated a relatively high prevalence of hostility, paranoia, and interpersonal sensitivity as the factors reflected in personal relationships. Although the women are more susceptible to psychosocial disorders, no statistically significant difference was found between the two genders, except for anxiety. Overall, anxiety is more prevalent in females with BD compared to the males, which might be due to the fact that men can cope with their disease better than women and, as a result feel less stress in their lives.

The psychological symptoms in BD could be aggravated by the illness itself or by the immunosuppressive drugs used during the treatment course. Also, it is suggested that these symptoms are secondary to the disease (18). Furthermore, these symptoms can interfere with the patients' healing process and quality of life; therefore, it is the physicians' duty to screen for these symptoms in the patients and refer them to the psychiatry service for further evaluation (19). In this way, they might prevent the progression of psychological problems of patients, decrease the relapse durations, and limit psychological symptoms from interfering with the treatment procedures in $\mathrm{BD}$.

The limitations of the present research include lack of control group and cross-sectional design, hence other factors potentially affecting the patients' current mental status could not be evaluated

\section{CONCLUSION}

The prevalence of psychological symptoms was remarkable in the patients with $\mathrm{BD}$. Therefore, the physicians should monitor their patients with BD in order to detect the possible psychiatric disorders they might develop during their disease.

\section{Acknowledgements}

The authors appreciate the help and support of Research Improvement Center of Shiraz University of Medical Sciences and Ms. A. Keivanshekouh for improving English of the manuscript. 


\section{References:}

1. Behçet H. Über die rezidivierende Aphtöse durch ein Virus verursachte Geschwüre am Auge und an den Genitalien. Dermatol Wochenschr. 1937;105:1152-7.

2. Berlin C. Behçet's syndrome with involvement of the central nervous system. Arch Dermatol Syphilol. 1944;49:227-33.

3. Tursen U GA, Boyvat A. Evaluation of clinical findings according to sex in 2313 Turkish patients with Behçet's disease. Int J Dermatol. 2003;42:346-51.

4. Epstein RS CN, Sherwood EB, Bergsma DR. Psychiatric aspects of Behcet's syndrome. Journal of Psychosomatic Research. 1970;14:161-72.

5. Tanriverdi N TÝ, Dürü Ç, Özdal P, Ortaç S, Firat E. Health-related quality of life in Behçet patients with ocular involvement. Jpn J Ophthalmol. 2003;47:85-92.

6. Borson S. Behçet's disease as a psychiatric disorder,Acase report. Am J Psychiatry. 1982;139:1348-9.

7. Monastero R CC, Pipia C,Lopez G, Camarda L, Baiamonte V, Triolo G, Camarda R. Cognitive impairment in Behcet's disease patients without overt neurological involvement. J Neurol Sci. 2004;220:99104.

8. Taner E CB, Burhanoflu S, Calikoflu E, Onder M, Arikan Z. Depression and anxiety in patients with Behçet's disease compared with that in patients with psoriasis. Int J Dermatol. 2007;46:1118-24.

9. Uhl V RV, Fromm J B Psychiatric symptoms in Behcet's syndrome. Psychosomatics: Journal of Consultation Liaison Psychiatry. 1985;26:547-9.
10. Ghaffari nejad A PF, Vahdati M. Mental disorders in girls younger than 15 years staying in supporting centers of Kerman in 2001. Rafsanjan University of medical science Journal. 2003;2:88-93.

11. Bagheri Yazdi SA BJ, Shah Mohammadi D. Epidemiology of mental disorders in sub rural areas of Meybod in Yazd state. Iranian Journal of Psychiatry and Clinical Psychology. 1992;1:32-42.

12. Noorbala A.A AM, Shalbafan A.R Psychological Dimensions in Patients admitted in Imam Khomeini General Hospital in Tehran. Iran J Psychiatry. 2010;5:51-4.

13. Shirmohammadi M AM, Taghizadeh Z, Haghanni H. Premenstrual Syndrome and Psychiatric Comorbidities. Iranian Journal of Psychiatry and Clinical Psychology. 2009;4:62-6.

14. Evereklioglu C CY, Doganay S et al. Audio-vestibular evaluation in patients with Behçet's disease. J Laryngol Otol. 2002;115:704-8.

15. Balbin EG IG, Solomon GF Stress and coping: the psychoneuroimmunology of HIV/AIDS. Baillieres Best Pract Res Clin Endocrinol Metab. 1999;13:615-33.

16. LipowskiZJ. Somatization: The concept and its clinical application. The American Journal Of Psychiatry. 1988;145:1358-68.

17. Blackford S FA, Roberts DL Quality of life in Behçet's syndrome:335 patients surveyed. Br J Dermatol. 1997;136:287-99.

18. R Karlidag SU, C Evereklioglu,B Sipahi,H Er,S Yologlu Stressful life events, anxiety, depression and coping mechanisms in patients with Behçet's disease. European Academy of Dermatology and Venereology. 2003;17:670-5.

19. Nejati safa AA BH, Sharifi Ale-Agha M, Rasooli F, Soroush AR, Amini H. []. 2009; 4:41-43. Recognition of Depression and Anxiety by Non-Psychiatric Residents in a General Hospital. Iranian Journal of Psychiatry and Clinical Psychology. 2009;4:41-3. 